\author{
НАТАЛИЯ ВАНОТ \\ Силезский университет (Катовице, Польша)
}

\title{
Смеховые элементы молодёжного жаргона. Словообразовательный анализ
}

Сленг и жаргон - эта тема была, есть и будет актуальной в современном языкознании. К сожалению, до сих пор она еще не вполне разработана. В разговорной речи молодёжь часто употребляет такие лексемы, которые засоряют литературный, нормативный язык. Эти слова молодые люди употребляют в общении друг с другом. В нашей статье мы попробуем мотивировать, почему молодёжь так любит употреблять жаргонизмы, а также встречаются ли эти слова в литературном языке или являются только средством разговорного контакта. Мы покажем также способы создания и образования лексем сленга. Используем для этого наиболее яркие примеры. Дефиниции таких понятий как сленг и жаргон мы взяли из Большого энциклопедического словаря В. Н. Ярцевой. Для примеров был использован материал Толкового словаря молодёжно-студенческого жаргона А. Маркунаса и словаря Слова, с которылм мы все встречались О. П. Ермаковой, Е. А. Земской и Р. И. Розиной.

Молодёжная культура - это свой, ни на что не похожий, мир. Мир, который отличается от мира взрослых практически всем. Молодёжь отличается от последних не только одеждой, увлечениями и стилем жизни, но и, прежде всего, языком. Язык молодых людей это своеобразный код. Код, который понимают только они сами. Молодые люди в ежедневном общении употребляют разные жаргонные лексические единицы.

По мнению В. Н. Ярцевой, жаргон - это «разновидность речи, которая используется преимущественно в устном общении отдельной социальной группой, объединяющей людей по признаку профессии, положения в обществе, интересов или в случае молодёжи - возраста. От общенародного языка отличается специфической лексикой, фразеологией и особым использованием словообразовательных средств. Часть жаргонной лексики - принадлежность не одной, а многих сощиальных групп. Переходя из одного жаргона в другой слова их могут менять значение и форму» (Ярцева 1998: 151).

Например, слово поляна, которое в общеупотребительном просторечии означает льсину, перешло в молодёжный сленг, в котором обозначает уже 
стол с выпивкой и закуской. Лексика жаргона нередко пополняется за счёт заимствований из других языков. Характер жаргонной лексики зависит от ценностной ориентации и характера социальной группы. О. Есперсен выделяет два виды групп: открытые и замкнутые. В открытых группах жаргон - это коллективная игра. В замкнутых группах жаргон является сигналом, который различает своего и чужого. Жаргонизмы чаще отражают юмористическое или фамильярное отношение к предметам действительности. Жаргонные выражения быстро проникают в литературный язык. Иногда термин жаргон применяют для обозначения неправильной речи. Поэтому его часто заменяют выражениями типа язык студенчества или терминами арго, сленг (Ярцева 1998: 151).

Молодёжная речь, которая отражает неустойчивое культурно-языковое состояние общества, находится между литературным языком и жаргоном. Молодёжь является носителем жаргона, делает его элементом поп-культуры, престижным и необходимым для самовыражения. Для молодёжного жаргона, в отличии от других жаргонов, характерно эмоционально-игровое начало. Молодёжь знает как необходимо говорить, однако говорит неправильно. Молодые люди используют часто непринятые формы слов, хотя знают правильные, нормативные варианты. Это происходит потому, что у них другая система ценностей, другая, часто противоположная к общепринятой, норма, которую можно назвать антинормой. Главный принцип этой антинормы вызвать у окружающих шок, встряску и насмешку, для того чтобы не было скучно, а стало смешно. В этом как бы выражается у молодых вызов обществу, неприятие его норм (Федорова 2000: http://rus.1september.ru/article. php?ID=200000401).

Молодёжь пользуется сленговой лексикой для того, чтобы противопоставить себя остальной части общества, например, преподавателям, родителям или представителям старшего поколения, которые, по мнению молодёжи, являются скучными или даже странными. Молодёжный жаргон пополняется, за счёт всего нового, нетрадиционного, отвергаемого. Это может быть речь музыкальных фанатов, лексикон наркоманов, компьютерный жаргон и городское просторечие, иностранный язык и воровской жаргон. Речь молодёжи характеризуется её первобытностью. Она нестабильна и постоянно меняется. Не успев закрепиться в ней, одни выражения уступают место другим. Ещё одним признаком «первобытности молодёжного жаргона» является неопределённость и размытость значений новых слов (Федорова 2000: http://rus.1september.ru/article.php?ID=200000401).

На молодёжном сленге общается сегодня немалое количество людей, которых объединяет возраст. Носителями сленга являются, как правило, молодые люди в возрасте от двенадцати до тридцати лет. Сленг охватывает все области их жизни, это постоянное словотворчество, в основе которого лежит принцип языковой игры. Молодому человеку важно не только «что сказать», 
но и «как сказать», чтобы быть интересным собеседником. Появление сленга в СМИ всегда вызывает неоднозначную реакцию. Некоторые его категорически не принимают. А молодёжь, наоборот, «видит в прессе и на телеэкране свою тусовку» (Поспелова 2010: http://www.lingvotech.com/sleng).

Собственно, молодые люди находятся в очень трудном положении: это уже не дети и ещё не взрослые. Такое положение молодёжи С. И. Левикова называет «двойственным положением» (Левикова 2004: http://www.philology. ru/linguistics2/levikova-04.htm). Молодые люди создают свой язык - жаргон, чтобы показать свою индивидуальность, независимость, свободу, показать, чем они отличаются от мира взрослых, часто скучных людей. Благодаря сленгу, молодые люди больше чувствуют связь со своими ровесниками, знакомыми. Сленг позволяет показать принадлежность к определённой общественной группе, группе, в которой молодой человек чувствует себя безопасно, группе, которая любит его и уважает.

Отметим, что сленг употребляется в любом возрасте, не только школьниками и студентами разных вузов. Долгое время основой такого языкового явления считался студенческий сленг. Студенты пользуются разговорной формой языка, характерной для своего уровня образования и развития. На сленг имеет влияние среда, а также разговорная речь, молодёжный язык, современная культура, американская культура и даже преступная среда, проникающая сегодня во все сферы деятельности человека. Важны также молодость, игра, открытость. Если закрытость - это черта жаргонов, особенно преступного мира и групп, которые сознательно хотят изолироваться от окружающего, то студенты - это открытая контактная группа, создающая свой язык не для того, чтобы отделиться от общества.

Речь студентов, как и речь молодёжи, играет словом, отличается чувством юмора и креативностью. Креативность очень важна и встречается далеко не во всех группах общества. Студенческий сленг выразителен и дает эмоциональную оценку предметам, представляя отношение к действительности через карикатурность, высмеивание, игру словом. Большинство сленговых выражений относится к сфере действительности, связанной с игрой, учёбой, жизнью в общежитии. Условия жизни и учёбы естественно отражаются в языке и являются зеркалом молодежной культуры, общественной студенческой жизни (Kidaliński 2009: 14-15).

Сленг умеет пользоваться метафорами. В нём мы находим различные группы слов и определений, например, девушки, которая получает зачёты за счёт своей внешности, студента, который многократно не сдаёт экзамен. Для студенческого сленга характерны выразительная лексика, чувство юмора. В вузы поступает молодёжь разных общественных групп, при этом каждая вносит свои элементы языка. Можно сделать вывод, что студенческий сленг действительно является основой молодёжного сленга в целом. 
В студенческим сленге можно увидеть лексемы, которые характерны для молодёжи в целом. Ведь и школьники, и студенты - это учащиеся группы, которые отражают сходную действительность, поскольку она связана с учёбой. Студенты высмеивают в речи своих преподавателей, а школьники своих учителей, студенты иронически называют предметы, и школьники тоже. Все - и студенты,и ученики - высмеивают старшее поколение, употребляя часто при этом одни и те же сленговые выражения.

Мы проанализировали около 1000 слов русского молодёжного и студенческого жаргонов. Остановимся на наиболее интересных примерах. Весь материал мы разделили на 3 основные группы. В каждой группе мы выделили несколько подгрупп. Первая выделенная нами группа - Учёба.

Эта группа содержит: названия выпускников (абита - абитуриент), обозначения популярных у студентов мест (бибел - библиотека), обозначения преподавателей (зарубка), обозначения директора школы (сторожректор школь), обозначения студентов и учеников (скалпель - студент медицины ), обозначения вузов и факультетов (cumem - университет), названия предметов, составляющих жизнь учащихся (считало - калькулятор).

В этой группе много заимствований из иностранных языков, прежде всего из английского (например, тичер - учитель). Это связано с тем, что английский язык пользуется популярностью среди молодых людей. Заимствованные слова подвергаются при этом фонетической и грамматической ассимиляции. Мы отметили также много сокращений основ общеупотребительных слов (например, преп - преподаватель или унвер - университет).

Следующая группа - это Omdblх и развлечения.

В этой группе мы выделили следующие подгруппы: названия музыкальных групп (Крем - рок группа Крематорий), названия инструментов (лоnата - гитара), названия магнитофона (бумбастик-магнитофон), названия игры на инструментах (чёс - игра на гитаре), названия мероприятий (фестивалить - веселиться), названия алкоголика (алкаш - алкоголик), названия бутылки спиртного (покойник - пустая бутылка), названия разных напитков (вайн - вино), названия похмелья (печень рассыпалась на атомы - сильное похмелье), названия наркотиков (пудра - кокаин).

В этой группе мы обнаружили много слов, связанных с приёмом наркотиков. Лексемы называют и сами наркотики, и действия наркоманов. Можно сделать вывод, что раньше слова, связанные с наркотиками, относились к закрытому лексикону. Сегодня это положение изменилось, поскольку молодёжь может столкнуться с наркотиками на каждом шагу.

В этой группе, как и в группе учёба, много заимствований из английского языка (например, денсить - танцеевать). Благодаря текстам песен разных музыкальных групп сленговые слова переходят в общеупотребительную речь (Бошетумнай - конопля). Это слово мотивировано названием песни группы $<$ Кино $>$ из альбома $<$ Группа крови $>$ написанной В. Цоем. 
Последняя группа это группа лексики - Человек и мир вокруг него.

В этой группе находятся названия средств транспорта (батон - авто$б y c)$, названия марок автомашин (запор - машина марки Запорожеи), названия национальностей (желток - азиат), названия человека по чертам характера (фраер - человек, которого можно обмануть), названия мест актуальных для молодых (шоп - магазин), названия частей тела (макаронbl - волосы), названия женщин (щанель номер ять - женщина), названия мужчин (бойфренд - парень), названия детей и родителей (кинд - ребёнок, мазер-мама).

В этой группе как и во всех группах много заимствований из иностранных языков, в частности, из английского (например, бойфриенд). Есть и заимствования из немецкого языка (например, кинд). Мы тоже обнаружили одно заимствование из идиша (например, фраер).

Каждая из этих групп по-своему интересна, но мы остановимся на подробном анализе сленговых лексем, называющих лиц мужского пола. Это позволит нам показать то, как и каким образом молодёжь образует сленговые единицы. В ходе анализа мы заметили следующие особенности и способы образования сленга:

- Суффиксация - в этом процессе слова образуются при помощи различных суффиксов.

- Усечение - способ, при котором усекаются, в основном, многосложные слова и словосочетания.

- Словосложение - объединение полнозначных слов или их основ в одно сложное слово.

Можно отметить тот интересный факт, что префиксация как способ словообразования в сленге для области номинации лиц не характерна.

- Заимствования - копирование слова или выражения из одного языка в другой.

При образовании новых сленговых слов характерен семантический перенос. Семантический перенос происходит, когда слова литературного языка используются в переносном значении. Общее направление переноса: c «не человек» - на человека. Метафорический перенос с человека на не человека почти никогда не используется при образовании сленга.

Наиболее продуктивным способом словообразования в русском сленге является суффиксация. Во время анализа слов мы заметили, что наиболее популярными суффиксами, которые образуют сленговые слова являются такие суффиксы как: -л-,-щиик, -ник-, -чик-, -yx-, -юx-. Теперь покажем это на примерах.

Суффикс -щик- в литературном языке выделяется в существительных, обозначающих лиц мужского пола по их профессиональному признаку, по их действиям. Например, тусовщик (тот, кто сам участвует в тусовках). Это слово образовано от слова тусовка, путём усечения суффикса -к- и добавления суффикса -щик-. 
Суффикс -чик- в литературном языке выделяется в существительных мужского рода с уменьшительно-ласкательным значением. В сленге этот суффикс используется в том же значении. Примером является слово графитчик - человек, который выполняет рисунки на стенах. Слово образовано от литературного слова граффити путём усечения основы и добавления суффикса -чик-.

Суффикс -ник- в нормативном языке выделяется в существительных, обозначающих лиц по отношению к занятию проффессии, деятельности. В сленге этот суффикс также называет лица по их отношению к определенному занятию и по манере поведения: научник - научный работник. Слово образовано от литературного слова наука, путём усечения флексии -а , и добавления суффикса -ник- и чередованием к/ч.

Следующий суффикс это суффикс -л-. Этот суффикс в литературном языке выделяется в существительных, которые называют лиц. В сленге этот суффикс производит от глагольных основ грубоватые наименования лиц по действию. Примером является слово водила-водитель. Слово образовано от глагола водить путём прибавления к основе суффикса -л-.

Последний суффикс - это суффикс -ухх-. В литературном языке этот суффикс мало продуктивен. В сленге выступает очень часто, с его помощью образуются не только слова мужского пола, но и женского. Примером послужит лексема ломовуха - большой, сильной человек. Слово образовано от слова лом, путём добавления суффиксов -ов- и -ух-.

Анализируя собранный нами материал, мы обнаружили несколько видов переноса, а именно:.

Перенос с названий растений на человека: помидор - стеснительный человек. Сленговая лексема мотивированная литературным словом помидор, обозначающим огородное растение с красным плодом. Когда человек стесняется, его лицо имеет красный цвет. Именно поэтому молодые люди называют стеснительного человека помидор.

Перенос 3 названий профессий на человека: инженер - глупьлй человек. Эта лексема мотивированная литературном словом инженер, которое обозначает специалиста с высшим техническим образованием. В сленге имеет противоположное значение. Ведь молодёжь часто использует нейтральные литературные слова в негативном значении.

Перенос с названий животных на человека: жираф - высокий человек. Лексема жираф мотивируется литературным словом жираф, обозначающим животное с очень длинной шеей. Животное жираф своим внешним видом и особенно ростом напоминает высокого человека. Поэтому в сленге высокий человек это жираф.

Перенос с названий предметов на человека: плуг - человек из сельской местности. Приведённая сленговая лексема мотивирована книжным словом плуг, которое обозначает сельскохозяйственное орудие труда. Молодые 
люди называют человека из сельской местности плугом, потому что это название ассоциируется им с деревней. Лексема эта имеет немножко грубоватую окраску.

Продуктивным способ образования сленговых лексем является также усечение основ. В этой группе мы обнаружили такие лексемы как преn преподаватель, слово образовано от литературного слова преподаватель путём усечения, наив - наивныій, глуповатый человек, слово образовано от литературного слова наивность путём усечения.

Последняя группа слов, которую мы хотим описать в данной статье, это заимствования. В настоящее время в сленг попадает очень много заимствований из разных иностранных языков. Это, может быть, связано с тем, что молодые люди часто выезжают за границу, где они узнают другой язык, а потом, в ежедневном общении, употребляют новые слова. Во время анализа мы подразделили заимствования на три группы:

Первая группа это кальки - этот способ образования включает в себя заимствования грамматически не освоенных русским языком слов. При этом слово заимствуется целиком со своим произношением, написанием, значением. Каждый звук в заимствуемом слове подвергаются ассимиляции. В этой группе находятся следующие лексические единицы: френд - друг (от английского слова friend), тичер - учитель (от английского слов teacher), драмер - музыкант, играющий на ударных инструментах (от английского слова drummer). Здесь хорошо заметно то, что все заимствованные слова имеют такие же корни, как оригинальные иноязычные слова, кроме того, они имеют такое же написание.

Вторая группа это полукальки - способ заимствования, в котором при переходе термина из одного языка в другой, последний язык «подгоняет» принимаемое слово под нормы не только своей фонетики, как в предыдущей группе, но и грамматики. При грамматическом освоении заимствуемое слово «поступает в распоряжение» русской грамматики, подчиняясь её правилам. К этой группе мы отнесли следующие слова: скейтер - любитель катания на роликах (от английского слова skate), фазер - nana (от английского слова father).

На этих примерах видно, что это не целиком заимствованные слова, поскольку они подверглись воздействию правил русской грамматики и фонетики.

После анализа собранного нами материала мы пришли к выводу, что самым распространённым способом образования сленговых единиц языка молодежи является суффиксация, а затем семантический перенос и заимствования. Но сленг не стоит на месте, он постоянно развивается. Каждый день возникают новые слова для обозначения явлений и предметов окружающей действительности. Поэтому возможно, что со временем один из продуктивных способов словообразования перейдет в непродуктивный, как и непродуктивный способ может стать продуктивным. 


\title{
Библиография
}

Akartel G. М. (2004), Лексико-семантические словообразовательные разряды существительных с суффиксами иноязычного происхождения в русском и польском языках, Katowice.

Czerwiński P. (2009), Жаргоны и сленг в аспекте оформления лексического значения слова, [в:] Современные жаргоны и их описание, ред. А. Зых, М. Надель-Червиньская, Katowice.

Kidaliński. B. (2009), Studencki slang - język zapisany w genach, [w:] Magazyn studentów: Semestr 12/2009, s. 14-15.

Markunas A. (2003), Толковый словарь молодёжно-студенческого жаргона, Poznań.

Wanot. N. ( 2012), Смеховая культура современной молодёжи в сленгах польском и русском, Niemcy.

Ермакова О. П., Земская Е. А., Розина Р. И. (1999), Слова, с которыми мы все встречались, Москва.

Левикова С. И. (2004), Молодёжный сленг как своеобразный способ вербализации бытия, http://www.philology.ru/linguistics2/levikova-04.htm.

Поспелова Т. Ю. (2010), Сленг, как явление в современной лингвистике, http://www.lingvotech. com/sleng.

Санников В. 3. (2006), Русский язык в зеркале языковой игры, Москва.

Федорова Л. Л. (2000), Современная молодёжная речь: норма или антинорма?, http://rus. 1september.ru/article.php?ID=200000401.

Ярцева В.Н.(1998), Большой энииклопедический словарь, Москва, с. 151.

\section{Natalia Wanot}

\section{Elements of laugh in youth slang. Word-formation analysis}

\begin{abstract}
Summary
The article is of research nature. It explains such notions as 'youth slang' and 'youth culture'. The article also presents the methods of word formation in slang. The collected research material has been subjected to a detailed analysis. Three main theme groups have been indicated. The first is SCIENCE group. The group contains words related to education: names of lecturers, names of school and university subjects, names of the school principal. The second is ENTERTAINMENT group. The group includes names of drugs and alcohol as well as names of music instruments. The last is MAN AND THE SOURROUNDING WORLD group. The group covers: names of means of transport, names of men and women. Moreover, a detailed analysis of word formation has been conducted. The aim of the article is to present youth culture and to indicate which methods of word formation are the most productive in the Russian youth slang.
\end{abstract}

